\title{
PENGEMBANGAN BAHAN AJAR FISIKA TERINTEGRASI ISLAM-SAINS UNTUK PESERTA DIDIK
}

\section{THE DEVELOPMENT OF PHYSICS TEACHING MATERIALS INTEGRATED WITH ISLAMIC-SCIENCE FOR STUDENTS}

\author{
Santih Anggereni1), Muh. Rusydi Rasyid2), Irma Uswatun Hasanah ${ }^{3)}$ \\ 1,2,3)Fakultas Tarbiyah dan Keguruan Universitas Islam Negeri Alauddin Makassar \\ santih.anggereni@uin-alauddin.ac.id ${ }^{1}$, muhammad.rusydi@uin-alauddin.ac.id ${ }^{2}$, \\ hasanahirmauswatun@gmail.com ${ }^{3}$ )
}

\begin{abstract}
Abstrak
Jenis penelitian ini adalah penelitian pengembangan. Penelitian ini bertujuan untuk mengembangkan bahan ajar fisika terintegrasi Islam-sains yang memenuhi kriteria valid, praktis dan efektif untuk peserta didik kelas VII MTs Guppi Samata Kab. Gowa. Model penelitian yang digunakan adalah model 4D yang terdiri atas define, design, development, dan disseminate. Instrumen penelitian yang digunakan adalah lembar validasi, lembar observasi keterlaksanaan bahan ajar, dan angket respons peserta didik terhadap bahan ajar. Sampel pada penelitian ini yaitu peserta didik kelas VII.C dan VII.D di MTs Guppi Samata Kab.Gowa. Data yang diperoleh kemudian dianalisis menggunakan analisis deskriptif. Hasil penelitian menunjukkan bahwa bahan ajar memenuhi kriteria sangat valid dengan nilai rata-rata sebesar 0,98 . Bahan ajar memenuhi kriteria praktis dengan nilai rata-rata sebesar 1,84 . Respons peserta didik berada pada kategori positif sehingga memenuhi kriteria efektif. Maka dapat disimpulkan bahwa bahan ajar fisika terintegrasi Islam-Sains layak digunakan sebagai sumber belajar kerena telah memenuhi kriteria valid, praktis dan efektif.
\end{abstract}

Kata Kunci: integrasi islam-sains, bahan ajar fisika, pengembangan bahan ajar

\begin{abstract}
This type of research is development research. This study aims to develop integrated Islamicscience physics teaching materials that meet valid, practical and effective criteria for grade VII students of Guppi Samata, Gowa Regency. The research model used is the $4 D$ model consisting of define, design, development, and disseminate. The research instruments used were validation sheets, observation sheets of the implementation of teaching materials, and questionnaires for students' responses to teaching materials. The samples in this study were students of class VII.C and VII.D in MTs Guppi Samata, Gowa Regency. The data obtained were then analyzed using descriptive analysis. The results showed that teaching materials met very valid criteria with an average value of 0.98. Teaching materials meet practical criteria with an average value of 1.84. Student responses are in the positive category so that it meets the effective criteria. Then it can be concluded that the integrated physics teaching material of Islam-Science is appropriate to be used as a learning resource because it meets valid, practical and effective criteria.
\end{abstract}

Keywords: islam-science integration, physics teaching materials, development of teaching materials 
How to Cite: Anggereni, S., Rasyid, M.R., \& Hasanah, I.U. (2019). Pengembangan bahan ajar fisika terintegrasi islam-sains untuk peserta didik. Al-Asma: Journal of Islamic Education, 1(1), 1-10.

\section{PENDAHULUAN}

Pendidikan adalah tindakan yang dilakukan oleh orang dewasa secara sadar terhadap anak yang terfokus kepada perkembangan anak agar anak tersebut mampu mencapai kedewasaannya dan menjalani segala aktivitasnya dengan mandiri (tanpa bantuan orang lain).

Menurut Undang-Undang Republik Indonesia No. 20 tahun 2003 tentang Sistem Pendidikan Nasional, disebutkan bahwa pendidikan adalah usaha sadar dan terencana untuk mewujudkan suasana belajar dan proses pembelajaran agar peserta didik secara aktif mengembangkan potensi dirinya untuk memiliki kekuatan spiritual keagamaan, pengendalian diri, kepribadian, kecerdasan, akhlak mulia, serta keterampilan yang diperlukan dirinya, masyarakat, bangsa dan negara (Depdiknas, 2003).

Pendidikan sangat penting dalam kehidupan manusia karena dengan pendidikan dapat menciptakan manusia yang berkualitas, berintelektual dan jauh dari kebodohan. Manusia yang berpendidikan atau berilmu tentu berbeda dengan manusia yang tidak berpendidikan atau tidak berilmu. selain menuntut ilmu merupakan kewajiban bagi setiap muslim, Allah swt juga berjanji akan meningkatkan derajat orang-orang yang berilmu. Sebagaimana yang telah dijelaskan dalam Alquran, terdapat banyak ayat Alquran yang menyebutkan keutamaan-keutamaan bagi setiap umat manusia untuk menuntut ilmu yang merupakan hal paling penting yang harus dimiliki tiap manusia, salah satu ayat tersebut terdapat dalam QS Al-Mujadalah/58: 11 sebagai berikut:

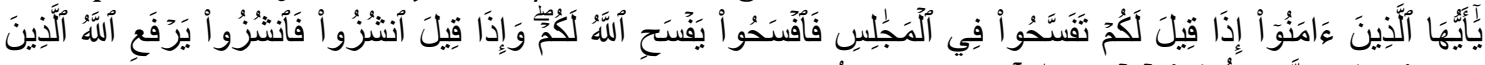

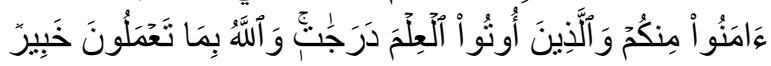

Terjemahnya:

Hai orang-orang beriman apabila kamu dikatakan kepadamu: "Berlapang-lapanglah dalam majlis", Maka lapangkanlah niscaya Allah akan memberi kelapangan untukmu. dan apabila dikatakan: "Berdirilah kamu", Maka berdirilah, niscaya Allah akan meninggikan orang-orang yang beriman di antaramu dan orang-orang yang diberi ilmu pengetahuan beberapa derajat. dan Allah Maha mengetahui apa yang kamu kerjakan (Kemenag, 2015: 543).

Salah satu faktor yang memengaruhi proses pembelajaran yakni penggunaan media pembelajaran, dalam hal ini adalah bahan ajar. Media pembelajaran merupakan segala sesuatu yang dijadikan perantara dalam proses pendidikan. guru profesional bukan hanya perlu mempersiapkan materi pelajaran saja, tetapi juga dituntut kreatif dalam hal menggunakan dan mengembangkan media pembelajaran. Media pembelajaran akan memudahkan interaksi antara guru dengan peserta didik sehingga kegiatan belajar akan lebih efektif dan efesien. Media pembelajaran yang dibuat juga harus dapat meningkatkan rasa keingintahuan peserta didik. Untuk menimbulkan rasa keingintahuan tersebut, maka dapat dilakukan dengan cara mengembangkan bahan ajar yang digunakan menjadi bahan ajar yang dapat menstimulus peserta didik untuk dapat berpikir kreatif pada proses pemecahan masalah dalam pembelajaran. 
Dewasa ini kemampuan memecahkan masalah peserta didik menurun karena model dan metode pembelajaran masih berpusat pada guru. Peserta didik belum diberi kesempatan yang luas untuk mengembangkan potensi dirinya, untuk meningkatkan kreativitas peserta didik perlu adanya media atau bahan ajar yang mengarahkan peserta didik ke proses berpikir yang kreatif terutama pada bidang sains.

Sains merupakan gelaja-gejala alam pada dimensi pengetahuan (keilmuan). Dengan begitu, pengetahuan dapat dikaitkan pada dimensi nilai ukhrawi, dimana dengan memperhatikan keteraturan di alam semesta akan semakin meningkatkan keyakinan akan adanya sebuah kekuatan maha dahsyat yang tidak dapat dibantah lagi, yaitu Allah swt. Dimensi ini menggambarkan hakikat sains adalah memautkan antara aspek logika-materil dengan aspek spiritual, yang selama ini dianggap cakrawala kosong, karena adanya suatu anggapan yang menyatakan bahwa sains dan agama merupakan dua sisi yang berbeda dan tidak mungkin dipersatukan dalam satu bidang kajian. Sementara pada kenyataannya terdapat ketertautan di antara keduanya (Ratnasari, 2016: 2).

Konsep integrasi Islam dan sains pada mata pelajaran fisika belum sepenuhnya diterapkan dalam proses pembelajaran. Selama ini penanaman nilai Islam tidak terintegrasi dengan pembelajaran fisika. Penyampaian materi belum ada yang dikaitkan dengan ayat Alquran. Hal ini dikarenakan guru hanya menyampaikan materi fisika secara umum seperti konsep hukum-hukum fisika dan persamaan yang menyertainya. Begitupun dengan soal-soal latihan yang hanya berisikan soal yang memuat konsep dan penggunaan persamaan fisika. Sementara itu, sebagai sekolah yang berada dalam naungan kementrian agama yang memiliki visi dan misi untuk membentuk siswa yang cerdas, terampil serta beriaman dan bertakwah kepada Allah swt, maka sudah seharusnya menghubungkan ayat Alquran dengan materi pembelajaran agar tidak ada pemisahan antara ilmu sains (fisika) dengan agama yang dikenal sebagai dikotomi ilmu pengetahuan.

Konsep integrasi Islam dan sains pada mata pelajaran fisika belum sepenuhnya diterapkan dalam proses pembelajaran. Selama ini penanaman nilai Islam tidak terintegrasi dengan pembelajaran fisika. Penyampaian materi belum ada yang dikaitkan dengan ayat Alquran. Hal ini dikarenakan guru hanya menyampaikan materi fisika secara umum seperti konsep hukum-hukum fisika dan persamaan yang menyertainya. Begitupun dengan soal-soal latihan yang hanya berisikan soal yang memuat konsep dan penggunaan persamaan fisika. Sementara itu, sebagai sekolah yang berada dalam naungan kementrian agama yang memiliki visi dan misi untuk membentuk siswa yang cerdas, terampil serta beriaman dan bertakwah kepada Allah swt, maka sudah seharusnya menghubungkan ayat Alquran dengan materi pembelajaran agar tidak ada pemisahan antara ilmu sains (fisika) dengan agama yang dikenal sebagai dikotomi ilmu pengetahuan.

Berdasarkan uraian di atas, maka penulis berinisiatif melakukan penelitian mengenai pengembangan bahan ajar fisika terintegrasi Islam-sains untuk peserta didik kelas VII MTs Guppi Samata Gowa. Bahan ajar adalah bahan atau materi pelajaran yang disusun secara sistematis berdasarkan prinseip-prinsip pembelajaran yang digunakan oleh guru dan siswa dalam proses pembelajaran (Sadjati, 2012: 5). Terdapat dua jenis bahan ajar yaitu bahan ajar cetak dan non cetak (Lestari, 2013: 67). Pengembangan adalah suatu proses atau langkah-langkah untuk mengembangkan suatu produk baru atau menyempurnakan produk yang telah ada dan dapat dipertanggung jawabkan (Sukmadinata, 2012: 164). 
Proses integrasi ilmu pengetahuan terjadi pada beberapa tingkatan. Ketika tingkat integrasi dicapai oleh peserta didik mereka akan mampu menghubungkan materi pelajaran mereka pada ilmu alam dengan keberadaan dan kebesaran Allah swt. Oleh karena itu, dalam rangka membantu peserta didik untuk mencapai tingkat integrasi, pengembang kurikulum pendidikan Islam di berbagai tingkatan harus menyertakan konsep integrasi antara Islam dan ilmu pengetahuan alam dalam kurikulum pendidikan Islam. Konsep ini akan menjadi jembatan untuk berhubungan antara ilmu-ilmu Islam dan ilmu alam.

Mengintegrasikan pendidikan sains dan akhlak dalam pembelajaran secara filosofis harus diberi muatan nilai-nilai fundamental. Pembekalan ayat-ayat Alquran misalnya dalam kaitanya dengan bidang studi yang bersifat universal dan humanistik. Hal ini merupakan proses penyadaran bahwa ilmu apapun tidak berdiri sendiri, dapat dicontohkan dalam Alquran memerintahkan kepada manusia untuk memperhatikan berbagai fenomena alam dan memikirkannya atau merenungkan keindahan berbagai ciptaan Allah swt, seperti langit, bumi, jiwa dan semua makhluk yang ada di jagat raya. Hal ini sudah dijelaskan dalam QS. Ali Imran/3: 190-191 sebagai berikut:

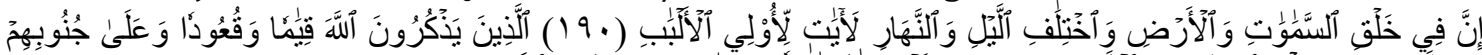

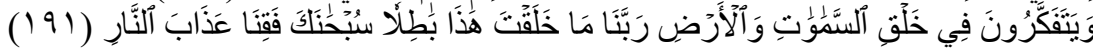

Terjemahnya:

(190) Sesungguhnya dalam penciptaan langit dan bumi, dan silih bergantinya malam dan siang terdapat tanda-tanda bagi orang-orang yang berakal; (191) (yaitu) orang-orang yang mengingat Allah sambil berdiri atau duduk atau dalam keadan berbaring dan mereka memikirkan tentang penciptaan langit dan bumi (seraya berkata): "Ya Tuhan Kami, Tiadalah Engkau menciptakan ini dengan sia-sia, Maha suci Engkau, Maka peliharalah Kami dari siksa neraka (Kemenag, 2015: 75).

Secara umum model integrasi keilmuan sains dan agama yaitu: Model IFIAS, Model Akademi Sains Islam Malaysia (ASASI), Model Islamic Worldview, Model Struktur Pengetahuan Islam, Model Becaillisme, Model Integrasi Keilmuan Berbasis Filsafat Klasik, Model Integrasi Keilmuan Berbasis Tasawuf, Model Integrasi Keilmuaan Berbasis Fiqh, Model Kelompok Ijmali, Model Kelompok Aligargh, dan Model kesatuan Berdasarkan Konsep Dasar. Menurut model kesatuan berdasarkan konsep dasar, kosep integrasi Islam sains ditentukan berdasarkan jumlah konsep dasar yang menjadi komponen utama model itu (Hamzah, 2015: 45-47).

\section{METODE PENELITIAN}

Jenis penelitian yang digunakan dalam penelitian ini adalah penelitian pengembangan (Research and Development). Research and Development (R\&D) merupakan perbaikan/pembaruan (improvement) dan perluasan (extension) dengan menekankan pada kebaruan dan produk nyata (Putra, 2015: 67-70). Penelitian pengembangan atau research and development (R\&D) adalah jenis penelitian yang dilakukan untuk menghasilkan prodak tertentu kemudian menguji keefektifan prodak tersebut (Sugiyono, 2015: 407).

Model penelitian dan pengembangan yang digunakan adalah model pengembangan 4D. Menurut Trianto (Trianto, 2015: 93) model pengembangan ini disarankan oleh Thiagarajan, Semmel, dan Semmel yang terdiri dari empat tahap 
pengembangan yaitu Define, Design, Develop, dan Desseminate atau diadaptasi menjadi model 4P yaitu pendefenisian, perancangan, pengembangan, dan penyebaran. Lokasi penelitian di MTs Guppi Samata, dan subjek uji coba produk hasil penelitian adalah peserta didik kelas VII. Instrumen yang digunakan pada penelitian ini adalah lembar validasi bahan ajar, lembar observasi keterlaksanaan bahan ajar dan respons peserta didik. Data yang diperoleh dari validator, observer dan peserta didik kemudian di analisis dengan menggunakan teknik analisis deskriptif.

\section{HASIL DAN PEMBAHASAN}

Penelitian ini merupakan penelitian pengembangan bahan ajar fisika terintegrasi Islam-sains pada materi tata surya untuk kelas VII MTs Guppi Samata Kab. Gowa. Penelitian ini bertujuan untuk mengembangkan bahan ajar fisika terintegrasi Islam-sains pada materi tata surya yang memenuhi kriteria valid, praktis dan efektif untuk peserta didik kelas VII MTs Guppi Samata Kab. Gowa.

Pada tahap define (pendefinisian) dilakukan analisis awal-akhir atau biasa disebut juga dengan analisis ujung depan dilakukan untuk menetapkan masalah dasar yang menjadi latar belakang perlu tidaknya dikembangkan bahan ajar dalam pembelajaran. Setelah melakukan observasi langsung di MTs Guppi Samata Kab. Gowa dan melakukan diskusi dengan guru mata pelajaran, peneliti memperoleh beberapa informasi diantaranya: Perangkat pembelajaran IPA yang selama ini digunakan adalah buku-buku paket IPA yang isinya lebih membahas materi IPA saja tanpa terintegrasi dengan ayat-ayat Alquran. Sedangkan sebagai sekolah yang berada dibawah naungan kementrian agama yang memiliki visi dan misi untuk membentuk peserta didik yang cerdas, terampil serta beriman dan bertaqwa kepada Allah swt, maka sudah seharusnya menghubungkan ayat Alquran dengan materi. Selanjutnya melakukan Analisis Peserta Didik (Learner Analysis), Pada langkah ini peneliti melakukan observasi untuk mengetahui kegiatan dan karakteristik dari siswa yang sesuai dengan rancangan dan pengembangan bahan pembelajaran serta sesuai dengan subjek penelitian yaitu peserta didik kelas VII MTs Guppi Samata Kab. Gowa, karakteristik peserta didik tersebut meliputi latar belakang pengetahuan dan perkembangan kognitif peserta didik kelas VII MTs Guppi Samata Kab. Gowa.

Analisis konsep (Concept Analysis) bertujuan untuk mengidentifikasi dan menyusun secara sistematis konsep-konsep yang akan diajarkan berdasarkan analisis awal-akhir. Berdasarkan kurikulum 2013 kelas VII semester genap, maka diperoleh analisis materi tata surya. Analisis Tujuan, Analisis ini bertujuan untuk merumuskan analisis konsep diatas menjadi indikator pembelajaran.

Deskripsi tahap design (perancangan) meliputi pemilihan format yang meliputi Kejelasan petunjuk penggunaan bahan ajar; Keserasian warna, tulisan dan gambar pada bahan ajar; Kesesuaian format sebagai tes formatif; Kesesuaian isian pada tes formatif dengan konsep/ definisi yang diinginkan; Kesesuaian pengintegrasian tiap sub materi dan ayat yang bersangkutan.

Setelah pemilihan format, selanjutnya dilakukan rancangan awal mengenai bahan ajar ini. Adapun yang menjadi rancangan awal bahan ajar ini yakni: cover bahan ajar dan isi bahan ajar. Pada tahap ini dihasilkan bahan ajar yang memuat materi tentang Tata Surya yang kemudian akan divalidasi oleh para validator. Rancangan awal dimulai dari 
sampul, kutipan dari beberapa ilmuan, kata pengantar, daftar isi, peta konsep, standar kompetensi dan indikator, pendahuluan, materi, rangkuman, uji kompetensi, kunci jawaban uji kompetensi, glosarium, penutup, tentang penyusun dan daftar pustaka yang beberapa desainnya dapat dilihat pada gambar diatas.

Pada tahap Development (Pengembangan), penulis menghasilkan prodak berupa bahan ajar yang telah melalui tahap validasi oleh validator sehingga layak digunakan dalam proses belajar mengajar didalam kelas. Bahan ajar yang dihasilkan selanjutnya divalidasi oleh dua validator yaitu dengan menelaah komponen penyajian, kelayakan isi, dan bahasa yang digunakan. Hasil validasi dari validator kemudian digunakan sebagai acuan dalam merevisi bahan ajar.

Tabel 1. Hasil Validasi Bahan Ajar Fisika Terintegrasi Islam-Sains

\begin{tabular}{clcl}
\hline No & \multicolumn{1}{c}{ Aspek Penilaian } & V & Keterangan \\
\hline 1 & Komponen Penyajian & 1 & Sangat Valid \\
2 & Komponen Kelayakan Isi & 0,98 & Sangat Valid \\
3 & Komponen Kebahasaan & 0,96 & Sangat Valid \\
\hline & Rata-rata Penilaian Total & 0,98 & Sangat Valid \\
\hline
\end{tabular}

Berdasarkan uraian hasil analisis di atas, nilai rata-rata total kevalidan bahan ajar adalah 0,98 . Sesuai kriteria kevalidan Indeks Aiken, nilai ini dinyatakan dalam kategori "sangat valid" $(\mathrm{V}>0,8)$.

Penelitian ini dilakukan di kelas VII.B MTs Guppi Samata selama 3 kali pertemuan digunakan untuk proses belajar mengajar, setiap kali pertemuan diawasi oleh dua orang observer yang kemudian pada pertemuan ke dua dan tiga kedua observer tersebut mengisi lembar observasi keterlaksanaan bahan ajar yang sudah disiapkan oleh peneliti. Pada pertemuan terakhir peneliti membagikan angket respons peserta didik terhadap bahan ajar fisika terintegrasi Islam-sains yang kemudian diisi oleh setiap peserta didik.

Tujuan utama analisis data keterlaksanaan bahan ajar adalah untuk melihat sejauh mana tingkat keterlaksanaan bahan ajar fisika terintegrasi Islam-sains diperoleh dalam proses pembelajaran. Selain itu juga untuk melihat kepraktisan modul dalam proses pembelajaran. Data pengamatan keterlaksanaan bahan ajar diperoleh melalui observasi yang dilakukan oleh dua orang observer yaitu: Djumaria, S.Pd (Guru mata pelajaran IPA kelas VII MTs Guppi Samata Kab. Gowa) dan Mihrab (Mahasiswa Jurusan Pendidikan Fisika UIN Alauddin Makassar).

Berdasarkan data hasil pengamatan, bahan ajar dikatakan terlaksana seluruhnya apabila memenuhi kriteria 1,5 $\leq \mathrm{M} \leq 2,0$. Sehingga dapat disimpulkan bahwa bahan ajar terlaksana seluruhnya karena memperoleh nilai rata-rata keterlaksanaan bahan ajar sebesar 1,84 serta bahan ajar memenuhi kriteria praktis untuk digunakan dalam pembelajaran. 
Hasil observasi keterlaksanaan bahan ajar dapat digambarkan dalam bentuk diagram sebagai berikut:

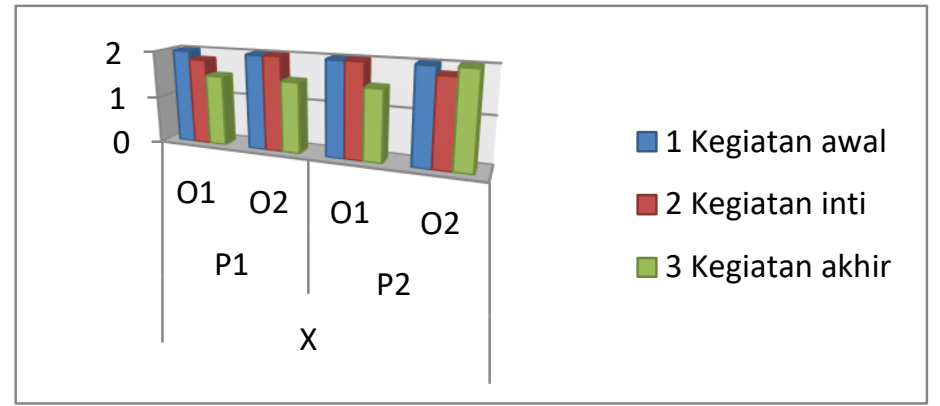

Gambar 1. Diagram Hasil Observasi Keterlaksanaan Bahan Ajar

Hasil respons peserta didik terhadap bahan ajar dapat digambarkan dalam bentuk diagram sebagai berikut.

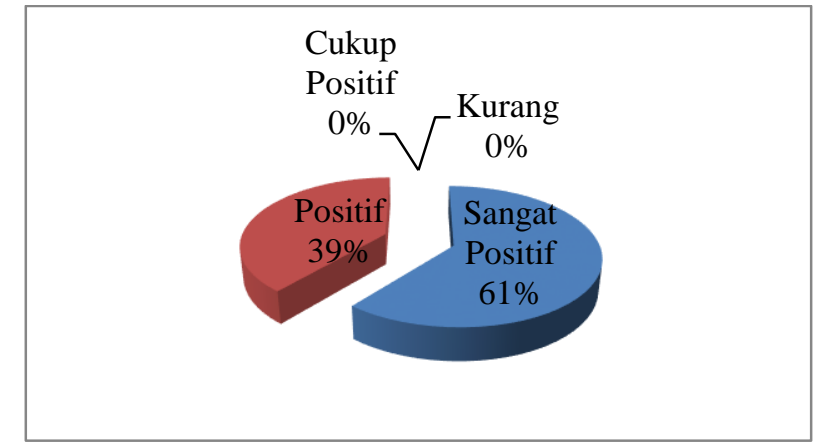

Gambar 2. Diagram Persentase Respons Peserta Didik

Jadi dapat disimpulkan bahwa bahan ajar yang dikembangkan dapat dikatakan efektif. Dari semua peserta didik, 61\% memberi respons sangat positif sedang 39\% lainnya memberi respons positif.

Tahap penyebaran (disseminate) merupakan tahap memperkenalkan bahan ajar fisika terintegrasi Islam-sains pada peserta didik. Pelaksanaan tahap ini dilakukan di dua lokasi berbeda pada waktu yang berbeda pula.

Dalam kegiatan tersebut diperkenalkan secara urut mulai dari item-item yang terdapat pada bahan ajar, materi fisika yang disertai ayat Alquran serta hadis yang sesuai. Penjelasan integrasi berikut nilai-nilai Islam yang dapat diambil dari ayat yang menjadi fokus integrasi serta memperlihatkan jenis soal-soal uji kompetensi yang mengintegrasikan pemahaman kosep fisika dengan ayat-ayat Alquran yang sesuai.

Bahan ajar fisika terintegrasi Islam-sains ini merupakan media pembelajaran pada materi tata surya untuk kelas VII.B yang dikembangkan melalui penelitian berbasis research and development (R\&D). Proses pengembangan bahan ajar ini melalui beberaa tahap sebelum menghasilkan bahan ajar yang baik dan layak untuk dgunakan dalam proses pembelajaran. Dalam proses pengembangan bahan ajar ini, model pengembangan yang digunakan adalah model 4D (Define, Design, Develop dan Dessiminate).

Tahap pertama adalah Define (pendefinisian) merupakan salah satu tahapan dari analisis kebutuhan bahan ajar sebelum dikembangkan. Pada tahap ini, peneliti melakukan observasi awal di sekolah yang menjadi lokasi penelitian guna melihat dan mendapatkan 
informasi langsung mengenai masalah-masalah yang dialami peserta didik dalam proses pembelajaran IPA, perihal karakteristik peserta didik dan strategi pembelajaran yang dilakukan oleh guru agar bahan ajar yang dikembangkan sesuai dengan tujuan pembelajaran yang ingin di capai.

Tahap berikutnya yaitu Design (Perancangan) pada tahap ini, bahan ajar yang akan dikembangkan terlebih dahulu dirancang dengan membuat garis-garis besar tentang bagian-bagian apa saja yang harus ada dalam bahan ajar seperti langkah-langkah atau tata cara penggunaan bahan ajar, materi bahan ajar, rangkuman, soal-soal latihan, glosarium dan daftar putaka serta pemilihan format guna menambah daya tarik dari bahan ajar yang akan dikembangkan agar sesuai dan layak digunakan dalam pembelajaran. Mulai dari mendesain cover, menentukan jenis dan ukuran tulisan, pemilihan gambar serta penentuan warna yang sesuai. Selanjutnya, membuat bahan ajar sesuai dengan apa yang telah direncanakan pada rancangan awal. Pembuatan bahan ajar ini hanya menggunakan satu aplikasi yaitu menggunakan microsoft word. Pada tahap ini ada beberapa kendala yang dihadapi diantaranya yaitu kurangnya referensi serta pemilihan bahasa yang sering kali kurang tepat dan tidak sesuai dengan usia peserta didik, serta pemilihan soal yang sesuai dengan usia perkembangan peserta didik.

Tahap berikutnya yaitu Develop (Pengembangan) Pada proses ini, terdapat beberapa saran dari validator mengenai apa-apa yang harus dihilangkan atau diubah dari bahan ajar. Setelah dilakukan revisi pada bahan ajar tersebut maka dilakukan validasi untuk memperoleh data kevalidan. Untuk memperoleh data kevalidan bahan ajar, peneliti menyiapkan instrumen berupa angket validasi bahan ajar yang menjadi alat untuk menghitung tingkat kevalidan bahan ajar. Bahan ajar dikatakan valid apabila hasil analisis sesuai dengan kriteria yang telah ditentukan. Berdasarkan analisis kevalidan, diperoleh bahwa bahan ajar yang dikembangkan masuk dalam kategori sangat valid dengan sedikit revisi. Rata-rata nilai hasil analisis validasi yaitu 1,0 untuk komponen penyajian; 0,98 untuk komponen kelayakan isi dan 0,96 untuk komponen kebahasaan. Sehingga diperoleh rata-rata nilai untuk keseluruhan yaitu $\mathrm{V}=0,98$.

Untuk uji kepraktisan bahan ajar diperoleh dari observasi keterlaksanaan bahan ajar yang dilakukan oleh dua orang observer. Guna memperoleh data kepraktisan, peneliti melakukan pengambilan data dikelas VII.B MTs Guppi Samata Kab. Gowa selama kurang lebih dua puluh hari dengan rincian sebanyak tiga kali pertemuan yang dilakukan sekali seminggu. Dalam proses pengambilan data yang dilakukan dilapangan, peneliti memperoleh beberapa kesulitan diantaranya untuk menghidupkan semangat belajar dan antusias peserta didik. Oleh sebab itu, pada pertemuan pertama peneliti mencoba untuk melakukan pendekatan kepada peserta didik sehingga membuat peserta didik tidak merasa canggung lagi pada pertemuan berikutnya. Pertemuan pertama dari total tiga kali pertemuan yang dilakukan peneliti ini digunakan untuk mengenal karakteristik peserta didik agar tidak terjadi hal-hal yang tidak diinginkan selama proses penelitian pada pertemuan-pertemuan berikutnya.

Kepraktisan diperoleh berdasarkan keterlaksanaan bahan ajar selama proses belajar mengajar. Hasil penilaian dua orang observer terhadap keterlaksanaan bahan ajar yang telah dikembangkan menunjukkan rata-rata keterlaksanaan bahan ajar sebesar 1,84 yang berarti bahan ajar yang telah dikembangkan ini memenuhi kriteria praktis. 
Untuk uji keefektifan bahan ajar diperoleh dari respons dan hasil belajar peserta didik. setelah melakukan proses pembelajaran dengan menggunakan bahan ajar. Berdasarkan data yang diperoleh, hasil analisis menunjukkan bahwa respons peserta didik sebesar $61 \%$ pada kategori sangat positif dan $39 \%$ pada kategori positif. Berdasarkan persentase tersebut, dapat dilihat bahwa bahan ajar yang dikembangkan efektif dengan kategori sangat positif. Meski terdapat beberapa persen pada kategori positif yang disebabkan oleh beberapa peserta didik yang kurang tertarik pada bahan ajar yang digunakan dengan alasan dari penampilannya masih kurang mampu menarik perhatian peserta didik. Sehingga beberapa peserta didik memberikan respons kurang tertariknya melalui angket respons peserta didik. Setelah respons peserta didik, dilakukan tes hasil belajar dimana peserta didik diuji kemampuan kognitifnya terhadap materi tata surya dengan mengerjakan soal pilihan ganda sebanyak 20 nomor dengan tingkat kesulitan soal berada pada ranah pengetahuan (C1) dan ranah pemahaman (C2). Rata-rata nilai peserta didik setelah melakukan pembelajaran dengan menggunakan bahan ajar yang dikembangkan adalah sebesar 78,26 yang berada pada kategori baik, dengan kategorisasi penilaian 9 orang mendapatkan nilai sangat baik dengan persentase sebesar 39\% dan sisanya sebanyak 14 orang peserta didik mendapatkan nilai baik dengan persentase sebesar 61\% sehingga dapat disimpulkan bahwa bahan ajar yang dikembangkan memiliki keefektifan yang baik ditinjau dari tes hasil belajar peserta didik.

Setelah serangkaian tahap dilalui, selanjutnya adalah tahap terakhir yaitu disseminate (penyebaran), bahan ajar yang telah melalui tiga tahap dari empat tahapan pengembangan model 4D yang telah melewati tahap uji coba produk. Penelitian ini dilakukan di MTs Guppi Samata Kab. Gowa untuk uji coba produk yang kemudian disebarkan atau disosialisasikan di MTsN 3 Buton Tengah. Tanggapan positif diperoleh dari sekolah yang menerima dengan baik bahan ajar yang akan diperkenalkan pada peserta didik di salah satu kelas VII yang ada disekolah itu.

Kelebihan dari bahan ajar ini adalah mempermudah proses belajar mengajar sebab hanya mengandung satu materi inti yang didalamnya telah terintegrasi dengan ayat Alquran sehingga peserta didik yang semula tidak mengetahui keterkaitan antar ayat dan materi menjadi tahu. Selain kelebihan, bahan ajar yang dikembangkan ini juga memiliki kelemahan yaitu bentuknya yang tak jauh beda seperti buku cetak pada umumnya membuat bahan ajar ini terlihat tidak begitu menarik bagi beberapa peserta didik. Solusi bagi bahan ajar yang akan dikembangkan selanjutnya adalah mengemas bahan ajar semenarik mungkin agar lebih meningkatkan kualitas bahan ajar yang akan dikembangkan.

\section{SIMPULAN}

Berdasarkan hasil penelitian dan pembahasan dari penelitian ini, maka dapat disimpulkan bahwa: (1) Tahap mengembangkan "Bahan Ajar Fisika Terintegrasi IslamSains untuk kelas VII MTs Guppi Samata Kab. Gowa" yaitu menggunakan model pengembangan perangkat pembelajaran 4D melalui 4 tahapan yaitu define, design, develop dan disseminate, (2) Hasil Pengembangan "Bahan Ajar Fisika Terintegrasi Islam-Sains untuk kelas VII MTs Guppi Samata Kab. Gowa" telah memenuhi kriteria valid, dengan nilai rata-rata total untuk kevalidan sebesar 0,98, (3) Hasil Pengembangan "Bahan Ajar Fisika Terintegrasi Islam-Sains untuk kelas VII MTs Guppi Samata Kab. Gowa” telah memenuhi 
kriteria praktis dan efektif dengan nilai rata-rata total untuk kepraktisan sebesar 1,84, (4) Hasil Pengembangan "Bahan Ajar Fisika Terintegrasi Islam-Sains untuk kelas VII MTs Guppi Samata Kab. Gowa" telah memenuhi kriteria praktis yang diambil dari nilai respons peserta didik yakni sebesar $61 \%$ memberi respons sangat positif dan sisanya sebanyak $39 \%$ memberi respons positif.

\section{DAFTAR PUSTAKA}

Depdiknas. (2003). Undang-Undang Republik Indonesia Nomor 20 Tahun 2003 tentang Sistem Pendidikan Nasional. Jakarta: Dharma Bhakti.

Hamzah, F. (2015). "Studi Pengembangan Bahan Ajar Pembelajaran IPA Berbasis Integrasi Islam-Sains Pokok Bahasan Sistem Reproduksi Kelas IX Madrasah Tsanawiyah. Jurnal Pascasarjana Universitas Muhammadiyah Siduarjo, 1(1), 45-47.

Kemenag. (2015). Alquran dan Terjemahnya. Jakarta: Dharma art.

Lestari, I. (2013). Pengembangan Bahan Ajar Berbasis Kompetensi Sesuai dengan Kurikulum Tingkat Satuan Pendidikan. Padang: Akademia Permata.

Putra. (2015). Research \& Develompment Penelitin dan Pengembangan: Suatu Pengantar. Jakarta: raja Grafindo Persada.

Ratnasari, L. (2016). Pengembangan Modul IPA Terpadu. Jurnal Pendidikan Fisika. Retrieved from https://scholar.google.co.id/scholar.asp

Sadjati, I. M. (2012). Pengembangan Bahan Ajar. Jakarta: UT Press.

Sugiyono. (2015). Metode Penelitian Kuantitatif dan Kualitatif R\&D (Cet. ke-17). Bandung: Alfabeta.

Sukmadinata. (2012). Metode Penelitian Pendidikan. Bandung: UPI.

Trianto. (2015). Konsep, Landasan, dan Implementasinya pada kurikulum Tingkat Satuan Pendidikan (KTSP). Jakarta: Kencana. 